\title{
Technology-Integrated Collaborative Learning: Convenient Al- ternative in Developing the Problem Solving Capability and Positive Attitude towards Mathematics
}

\author{
W Wawan ${ }^{1}$, M Marsigit ${ }^{1}$, Eka Fitria Ningsih ${ }^{2}$, Santi Widyawati ${ }^{2}$, Wahyu Kusumaningtyas ${ }^{2}, M^{2}$ Mahmudi $^{2}, S$ \\ Suhono $^{2}$, Ahmad Mukhlishin ${ }^{2}$, Fredi Ganda Putra ${ }^{3}$, Agus Setiawan $^{2}$ \\ ${ }^{1}$ Universitas Negeri Yogyakarta, Yogyakarta, Indonesia \\ ${ }^{2}$ Institut Agama Islam Ma' arif NU (IAIMNU) Metro Lampung, Indonesia \\ ${ }^{3}$ Universitas Islam Negeri Raden Intan Lampung, Indonesia \\ *Corresponding author E-mail: awanwawan0215@gmail.com
}

\begin{abstract}
This research is aimed to describe a technology-integrated collaborative learning, exploring the student perception associated with the implemented learning method as well as observing the effectiveness of this method compared to the individual method. This research was conducted in Islamic Institute of Ma'arif NU Metro - Indonesia in 2017/2018 academic year. Through the application of cluster random sampling technique, about 28 students were determined as the research sample. The research sample was the fifth semester students of mathematics education who are currently learning the geometric transformation subject. The experimental class which becomes the focus of researcher is consist of 28 students who were derived from the cluster random sampling technique. This research design is a mixed research. Observation sheet, interview, and test of problem solving capability were used as the data collecting instrument. The results of this research indicates that the collaborative process is performing well. The learning process was conducted in the class, not in the computer laboratory. The limited number of laptop did not impact the learning process. The observation results indicate that the level of student enthusiasm in following the learning process is adequately high. The positive comments from students show that the technology-integrated collaborative method has supported them to comprehend the mathematics concepts as well as growing the high intention of learning. Negative comments that occur are associated with the complexity of studied material and the difficulty in using the application for a small number of students. The test results of problem solving capability has shown that the method of technology-integrated collaborative learning provides better results compared to the individual learning..
\end{abstract}

\section{Introduction}

The rapid transformation and development in global world requires someone to become flexible, able to take initiative, able to lead when needed, and able to produce something new and useful in life. In order to properly hold the work responsibility in the information era, the graduates of an education institution need to think deeply regarding the way to solve problem creatively, working in a team, communicating clearly in various media, learning the ever changing technology, and able to manage the amount of received information [1] and [2] mentioned that the business actors in 21 centuries have determined that an employee has to be a critical thinker, effective collaborator, innovator, and good communicator. This argument is supported by the opinions of [3] which mentioned that the companies, organizations, and countries in 21 centuries will be interested to discover most qualified human resources to contribute in the advancement of knowledge creation. By considering those several condition, it is important for the students to conceive skills/capabilities that support the transformation of the information era in 21 centuries. The 21 century skills/capabilities area including the capability of solving problem and the capability of thinking creatively as the important competencies which required by the graduates in order to solve the contemporary life issues that tend to relatively complex. However, these various skills are unable to be mastered properly by most of the students in Indonesia. This condition is indicated by the low level of those competencies in the learning process on almost the entire subjects, including the mathematics learning.

Reviewing the mathematics learning in Indonesia, it is known that the basic mathematic skills of students are still categorized as low. According to the research conducted by [4], it is acquired an information that there are many students in Indonesia who still have difficulties in learning the basic materials of mathematics, such as the difficulty in arithmetic skill, the use of an equal sign/symbol, understanding the algebra expression, and understanding the concept of variable. According to the research result of [5], it is also known that the mathematics problem solving capability of students is still categorized as low. If compared to the mathematics 
skills/capabilities at the international level, the achievement results/values are still below the average of countries enlisted in the Organization for Economic Cooperation and Development (OECD), although in 2016 there are increasing values/achievements from the Program for International Student Assessment (PISA) and indicating that there is a significant improvement of Indonesian education which amounted to 22.1 point compared to the previous year. (Kemendikbud, 2017). If reviewed from the results of Trends International Mathematics and Science Study (TIMSS) in 2015, convenient results are acquired. Based on the learning hours, Indonesia is still the longest between the other countries, however the learning quality is still not good. In the results of 2015-TIMSS, Indonesia is still ranked 44 among 50 countries that surveyed based on the category of the mathematics capability.

By referring to those various issues, new challenge has occurred for the contemporary lecturers to change their way in preparing the learners in the future. The non-optimal competency of students in the learning process is also possibly caused by the learning model which implemented by lecturers in the class that indeed less appropriate. This condition is similar with what expressed by [6] who mentioned that one of the factors that influence the student learning is the learning approach factor which includes method and strategy used in the learning activities.

The rapid growths of information technology and children enthusiasm in using the information technology have to be utilized by lecturers in developing better mathematics learning. Several prior studies have been conducted (for example: [7]-[17] which indicated that through technology, the skills of students in mathematic could increase. This condition is surely able to become a golden opportunity for lecturers in implementing technology-based learning to improve the mathematics learning process. Through the utilization of technology, in one side the learning process would be fun, and on the other side will generate contributions towards the improvements of the skills required by students in 21 centuries. The entry of technology towards mathematics learning is certainly has to be wrapped properly, therefore, the learning process could run appropriately. By providing the opportunity for students to explore the knowledge through the technology which performed in group is considered as effective in optimizing the capability of students in mathematics. The role of lecturer as the mediator is one of the keys in the learning process if the development of problem solving capability is attempted to run in optimal manner[18], [19]. The collaboration between students in which they are provided with the opportunity to mutually give learning support and evaluation is necessary to be conducted, and this model learning format is what available in the collaborative learning method. Collaborative learning is one of the approaches that can be used by lecturers to optimize the learning results. There are many researches which indicate that the collaborative learning has provide positive impacts in the mathematics learning (see [8]; and [20].

Looking at those conditions, the author is interested to see the effectiveness of the method implementation of a technologyintegrated collaborative learning in mathematics as well as observing the learning process and learner perception towards the implementation of this method. This research is expected to become the inspiration material and reference for teachers or lecturers in managing the contemporary mathematics learning in order to support the competencies achievement of the graduates in 21 centuries.

\section{Research Methods}

This research is a part of bigger studies which observing the effectiveness of collaborative learning with the support of GeoGebra compared to the individual method in mathematics learning. In this research, the author is more focusing on the experimental class to see in further the learning process and student perception on the learning method applied to the class. Mixed method re- search is the method used in this research. The qualitative approach with case study design is used to look descriptively regarding the learning process and to explore the student perception towards the method implementation of technology-integrated collaborative learning. The quantitative research with a quasiexperimental design is a bigger research of this research which used to see the effectiveness of the method of technologyintegrated collaborative learning compared to the controlled class which accustomed to the individual method.

This research is conducted in Islamic Institute of Ma'arif NU Metro - Indonesia in 2017/2018 academic year. The research sample was the fifth semester students of mathematics education who are currently learning the geometric transformation subject. The experimental class which becomes the focus of researcher is consist of 28 students who were derived from the cluster random sampling technique. Observation sheet, interview, and test of problem solving capability were used as the data collecting instrument. Observation is used to observe the learning process, interview is used to discover the student perception associated with the learning process, while test is used to see the problem solving capability of students. The problem solving capability of mathematics is the learning results which being measured in this research. The effectiveness of this method is seen from final test results after the experiment is finished.

\section{Results and Discussion}

The GeoGebra-integrated collaborative learning is performed in the class, not in the computer laboratory. This condition which facilitates the implementation of the learning method. The learning process on the geometry transformation material is started through apperception, the objectives briefing and the lecturer explanation regarding the learning procedure that will be performed. As the part of the initial activities, students are given the opportunity to create groups based on their own desires. One group consists of 2 to 4 people. At this stage, some students have seen in confusion of determining which groups to follow that makes the class situation to be quite noisy. However, this noisy is not last for long, just around 10 minutes, after that, some students are seen to directly create groups by arranging chairs and selecting the desired groups. Most of the groups are made based on the proximity of the student's seat before the grouping is set.

After the grouping process is done, some students put out their laptops to be used in the learning process. The utilization of laptop for each group is limited to one laptop. This condition is meant for the collaborative learning to happen in optimal manner. The first meeting is used to provide the basic materials and the flow in constructing various forms of transformation result through the use of GeoGebra. The material delivered in the first meeting is translation.

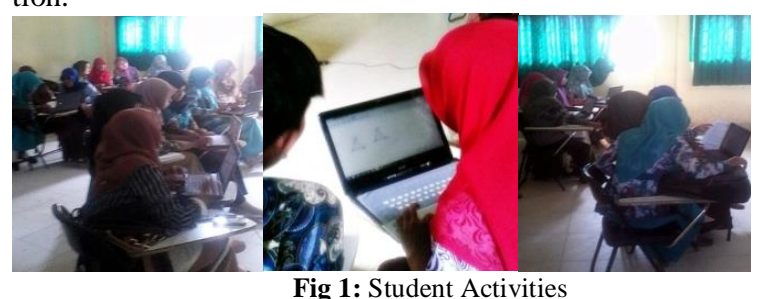

In the second meeting, the learning has been performed in conducive manner. In the early learning process, lecturer gives introduction, then the students work in their respective groups. In the second meeting, the students seem enthusiastic in following the lesson. This condition is seen from the number of questions submitted to lecturer regarding the materials that being learned. The questions are more associated with the material concepts rather than the application of GeoGebra. The learning process in this meeting is seems convenient, the students are sometimes express funny words that cause the class to be in anon-tensed situation. 
The collaborative learning also has been running decently. Some students are looking busy of giving help to others who have not been properly mastered the materials. The third and the follow-up meetings have been performed decently.

In this experiment class, the collaborative learning is implemented on the entire meetings, however, the application of GeoGebra is not conducted in every meeting. This condition is the adjustment for the materials that being learned. In the time students learn to comprehend the construction of a geometric shape after the application of a certain transformation, thus, the GeoGebra is used, however, during their time learning the theorems and the application in solving a mathematics issue, only collaborative learning that implemented in the class. During 8 (eight) learning processes associated with the materials of translation, reflection, rotation, and dilatation, four of them are performed with the support of GeoGebra in the learning process. The responses of students on the implementation of GeoGebra-integrated collaborative learning method are quite varied. A lot of positive comment is given although the negative comment from a student is still appear. Negative comment is usually emerging in relation to the complexity of materials that has to be studied, especially what related to the verification of the related theorems, while the positive comments are more about the collaborative method and the use of computer application.

In relation to the collaborative learning, almost the entire students are giving positive comments in which they felt facilitated by their friend's explanations. Even though, there is student who gives negative comment in which he is confused by their friend's explanations. The learning process through this method is also considered fun/convenient. They perceive the learning process as more relaxing during the collaboration. They feel free in asking or providing explanations to the other students.

Students also give various comments regarding the implementation of GeoGebra in the learning process. The positive comments by students are seen from the answers of students during the conducted interview, such as "this program is really helping me in understanding the materials", "it is quite fun using this application", even some of them said "why didn't this method is taught before sir". Some students said that after they comprehend the utilization of this application, they won't use a Microsoft word to draw the geometric shape anymore but instead use this application for the task in discussion. There is one student who expressed that he will use this application for his thesis. Some of these statements are indicating that this application is quite helpful and generating interests for students to use it in further.

When they were asked about their capabilities after learning with GeoGebra, they are merely said that the learning process of the material is getting easier, however they have yet to mention whether they are confident to be able of solving the questions provided by lecturer in the exam. Negative comment which occurs in the implementation of this application is that one student felt the application of this software is quite complicated, there is a lot of instruction that have to be conducted to get to a particular transformation result. The doubt of students in the experimental class is associated with their capabilities in mathematics which indicated from the test result of problem solving capability that performed in the end of the experiment. According to bigger research results, it has been discovered that the experimental class has better learning results compared to the controlled class, namely the class treated with an individual method. The results of statistic test on the bigger research through the utilization of 3-Ways ANOVA as the data analysis technique are shown below.

Table 1: Statistic Test Results

\begin{tabular}{|l|l|l|l|l|l|}
\hline Source & $\begin{array}{l}\text { Sum of } \\
\text { Squares }\end{array}$ & df & $\begin{array}{l}\text { Mean } \\
\text { Square }\end{array}$ & F & Sig. \\
\hline Method & 22,204 & 1 & 22,204 & 7,546 &, 007 \\
\hline Interest & 33,004 & 1 & 33,004 & 11,217 &, 001 \\
\hline Gender & 7,704 & 1 & 7,704 & 2,618 &, 108 \\
\hline Method * Interest & 51,338 & 1 & 51,338 & 17,447 &, 000 \\
\hline
\end{tabular}

\begin{tabular}{|l|l|l|l|l|l|}
\hline Method * Gender & 90,038 & 1 & 90,038 & 30,600 &, 000 \\
\hline Interest * Gender &, 504 & 1 &, 504 &, 171 & 680 \\
\hline Method * Interest * Gender & 3,504 & 1 & 3,504 & 1,191 &, 277 \\
\hline
\end{tabular}

In the learning method with $5 \%$ significance level, it is acquired that $\mathrm{F}_{\mathrm{obs}}=7,546$ and $\mathrm{Sig}=0,07$. According to the test result, it is known there is a significant difference between the experimental class and the controlled class. Because the mean of the experimental class is higher than the controlled class, thus, it can be concluded that the technology-integrated collaborative learning method has provided a better learning result compared to the individual learning.

If seen from each interest category, it is known that in the technology-integrated collaborative learning, the students with high interests are having better learning results compared to the students with low learning interests. Meanwhile, in the individual learning, it can be seen that the students with high and low interests are having the same learning results. In the collaborative method, it is also known that the learning achievements of female students are better than the male students, this condition is obviously in the contrary with the controlled class. This result is assumed to be caused by the number of female students in the experimental class which larger than the male students, while the opposite results occur in the individual class. Interactions between method, interest and sexes towards the problem solving capability can be seen through diagrams below.

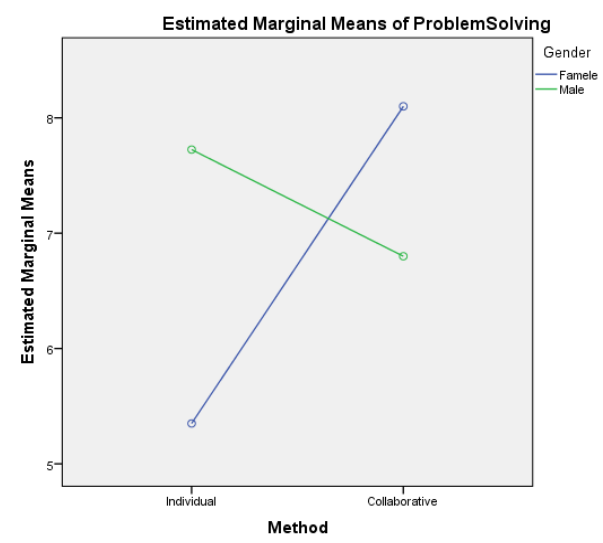

Fig 2: Interactions between method, interest, and sexes

According to the results of this study, it can be seen that both in qualitative and quantitative contexts, GeoGebra-integrated collaborative learning method provides positive impacts on the process and the results of mathematics learning. This result is parallel with the previous studies regarding the effectiveness of collaborative method in the learning process ([8]; [21] and [20]) and the benefits of GeoGebra in mathematics learning ([10]; [11]; [22]; [13]; [14]; and [15]). The application of GeoGebra software which is quite easy and can be used freely has been facilitated the implementation of this software in the mathematics learning. A teacher or lecturer who intends to use this software should not be occupied of bringing the learner to a computer lab. Learners do not have to move from their classes to be able to use this software, instead they can use it freely at their homes. This learning process also only requires couple of laptops, it means that not all learners must own a laptop. One laptop is enough to be used in the learning process for each group. The limitation of the number of laptops is conducted purposively in order for the collaborative learning to occurs.

High interest of students towards the application of GeoGebra software as concluded from this research results can be put into a consideration for teachers or lecturers that the implementation of this software in the mathematics learning is not a difficult thing. The enthusiasm of youth towards technology can be used by teachers/lecturers to improve the mathematic learning achievement as what presented in this research. The technology-integrated collaborative learning is in fact not a complicated strategy to be implemented in a mathematic class. 
By comprehensively paying attention to the results of this research, it can be seen that although the implementation of this method is providing positive impacts, however, the lecturers should consider the perception of students in implementing this model. The situation of the class which tends to be noisy during the distribution of group, the difficulty in comprehending the complexity of the materials as well as the difficulty of low grade students in using the provided application could become important lessons for lecturers to seek for alternative solutions in reducing these weaknesses. The lack of skills in collaborating and the competency of students are indeed become the inhibiting factors in a collaborative learning see [23]. Based on these conditions, lecturers should have prepared properly when intending to use this method in a mathematics learning. Preparing the students for group assignment, considering the availability of supporting media/facilities, giving routine feedbacks as well as improving the comprehension of students with low capabilities/skills through individual tasks could become considerations for lecturers.

The implementation of technology-integrated learning method in this research is still known to be unable of providing high selfefficacy level of students. The students who are still unsure whether they able to solve the problems given by lecturers should acquire special attentions. This action should be conducted because the self-efficacy of students is still in the low category in which according to a social cognitive theory, the efficacy is highly influencing the learning results [24]. Based on this reference, the lecturers should use individual assignments for students who are still lacking comprehension in the learning process. The collaboration process by presenting the diligent students in mathematics learning to explain the concepts towards the other students might be able to transfer skills on the other students, however, this method will not much improve the self-efficacy of students to be capable of properly learning or doing assignments on their own efforts As a solution, establishing the students who good at mathematics to build a self-efficacy should be followed by individual practice for the less-skilled students [24].

\section{Conclusion}

According to the observation results, it is known that the implementation of GeoGebra-integrated collaborative method is quite easy to execute because it is conducted in the class by using limited number of laptop. Although in the beginning of learning process is quite noisy during the distribution of group, however, this situation did not last for long. The student's enthusiasms appear in the second meeting which indicated by the questions asked by students related to the materials that being learned. In the second and the follow-up meetings, the collaboration process has been seen to run properly. The student perception also shows that this method is really helping them to comprehend the learned materials. Their interests towards the application that being used are also adequately high. The learning through this method also makes the class situation be in relax and non-tensed conditions. The negative comments that appear are associated with the complexity of materials that have to be studied and the difficulty in using the GeoGebra application for small part of the students. Although this method provides positive results towards the learning results, however, the self-efficacy of students has been discovered to be in a poor category. The individual assignments for students who are not already comprehend the materials could be an alternative solution if the lecturers are intending to implement the collaborative learning in a mathematics learning.

\section{References}

[1] T. L. T. Friedman, "The world is flat: A brief history of the twentyfirst century," New York Farrar, Straus Giroux, p. 660, 2007.

[2] M. Lewney, "Weapons of mass instruction," Physics World, vol. 22, no. 6. p. 52,2009 .
[3] James Bellanca and Ron Brandt, Rethinking How Students Learn, vol. 15. 2010.

[4] A. Jupri, P. Drijvers, and M. Van den Heuvel-Panhuizen, "Student difficulties in solving equations from an operational and a structural perspective," Int. Electron. J. Math. Educ., vol. 9, no. 1-2, pp. 39$55,2014$.

[5] W. N. Shanti and A. M. Abadi, "Jurnal riset pendidikan matematika," Ris. Pendidik. Mat., vol. 2, no. November, pp. 162174, May 2015.

[6] M. Syah, Muhibin. Psikologi Pendidikan dengan Pendekatan Baru. Remaja Rosdakarya, 2008.

[7] V. Švecová, L. Rumanová, and G. Pavlovičová, "Support of Pupil's Creative Thinking in Mathematical Education," Procedia - Soc. Behav. Sci., vol. 116, pp. 1715-1719, 2014.

[8] A. A. Gokhale, "Collaborative Learning Enhances Critical Thinking," J. Technol. Educ., vol. 7, no. 1, pp. 22-30, 1995.

[9] E. Kartikadarma, T. Listyorini, and R. Rahim, "An Android mobile RC4 simulation for education," World Trans. Eng. Technol. Educ., vol. 16, no. 1, pp. 75-79, 2018.

[10] R. A. Saha, A. F. M. Ayub, and R. A. Tarmizi, "The effects of GeoGebra on mathematics achievement: Enlightening Coordinate Geometry learning," Procedia - Soc. Behav. Sci., vol. 8, no. 5, pp. 686-693, 2010.

[11] Y. Zengin, H. Furkan, and T. Kutluca, "The effect of dynamic mathematics software geogebra on student achievement in teaching of trigonometry," Procedia - Soc. Behav. Sci., vol. 31, no. 2011, pp. 183-187, 2012

[12] S. R. Belgheis, "The Intention to Use GeoGebra in the Teaching of Mathematics among Malaysian Teachers.," Malaysian Online J. Educ. Technol., vol. 6, no. 1, pp. 109-115, 2018.

[13] P. Kllogjeri, "GeoGebra in Teaching and Learning Mathematics in Albanian Secondary Schools GeoGebra in Teaching and Learning Mathematics in Albanian Secondary Schools," 2015.

[14] K. K. Bhagat and C. Y. Chang, "Incorporating GeoGebra into geometry learning-A lesson from India," Eurasia J. Math. Sci. Technol. Educ., vol. 11, no. 1, pp. 77-86, 2015.

[15] C. Pfeiffer, "a Study of the Development of Mathematical Knowledge in a Geogebra- Focused Learning Environment," no. December, 2017.

[16] N. Nasrudin, I. Agustina, A. Akrim, A. S. Ahmar, and R. Rahim, "Multimedia educational game approach for psychological conditional," Int. J. Eng. Technol., vol. 7, no. 2.9, pp. 78-81, 2018.

[17] S. Sriadhi, R. Rahim, and A. S. Ahmar, "RC4 Algorithm Visualization for Cryptography Education," J. Phys. Conf. Ser., vol. 1028, no. 1, p. 012057 , Jun. 2018

[18] J. Simarmata et al., "Prototype Application Multimedia Learning for Teaching Basic English,” Int. J. Eng. Technol., vol. 7, no. 2.12, pp. 264-266, Apr. 2018.

[19] D. Napitupulu et al., "Analysis of Student Satisfaction Toward Quality of Service Facility,” J. Phys. Conf. Ser., vol. 954, no. 1, p. 012019, Jan. 2018.

[20] E. Retnowati, P. Ayres, and J. Sweller, "Can Collaborative Learning Improve the Effectiveness of Worked Examples in Learning Mathematics?,” J. Educ. Psychol., vol. 109, no. 5, pp. 1$14,2016$.

[21] J. Edwards and K. Jones, "Students' Views of Learning Mathematics in Collaborative Small Groups," 23rd Conf. Int. Gr. Psychol. Math. Educ., vol. 2, pp. 281-288, 1999.

[22] H. Zulnaidi and E. Zakaria, "The effect of using GeoGebra on conceptual and procedural knowledge of high school mathematics students," Asian Soc. Sci., vol. 8, no. 11, pp. 102-106, Aug. 2012.

[23] H. Le, J. Janssen, and T. Wubbels, "Collaborative learning practices: teacher and student perceived obstacles to effective student collaboration," Cambridge J. Educ., vol. 48, no. 1, pp. 103$122,2018$.

[24] D. H. Schunk, Learning theories, vol. 53, no. 9. 1996. 